\title{
PENGKLUSTERAN PENJUALAN BAHAN BANGUNAN MENGGUNAKAN ALGORITMA K-MEANS
}

\author{
Febri Hadi'), Yusvi Diana ${ }^{2)}$ \\ ${ }^{1}$ Fakultas Ilmu Komputer, Universitas Putra Indonesia YPTK Padang, Jln. Raya Lubuk Begalung \\ Padang \\ ${ }^{2}$ Fakultas Ekonomi dan Bisnis, Universitas Putra Indonesia YPTK Padang, Jln. Raya Lubuk Begalung \\ Padang \\ email: ${ }^{1}$ febri_hadi@upiyptk.ac.id, ${ }^{2}$ yusvi_diana@upiyptk.ac.id
}

\begin{abstract}
The large number of building material items at the Persada Building Store makes the store experience difficulty in processing sales data, for that, clustering is done using the K-Means algorithm, to find out which building materials are in demand and which building materials are not in demand.As for the purpose of this study is to gain knowledge in classifying building material sales. $K$-Means algorithm will cluster sales of building materials so that knowledge is used to make decisions in building materials sales. Data mining can produce a variety of knowledge, one of which is to determine the building materials that are most common in the sales transaction process. So that building materials that have the most sales transaction processes can be analyzed in the procurement of building material stock
\end{abstract}

Keywords: K-Means Algorithm, Cluster, Building Materials

\begin{abstract}
Abstrak
Banyaknya item-item bahan bangunan pada Toko Bangunan Persada membuat toko tersebut mengalami kesulitan dalam pengolahan data penjualan, untuk itu dilakukan pengklusteran dengan menggunakan algoritma K-Means, untuk mengetahui bahan bangunan mana yang laris terjual dan bahan bangunan mana yang tidak laris terjual.Adapun tujuan penelitian ini adalah mendapatkan suatu pengetahuan dalam mengelompokkan penjualan bahan bangunan. Untuk pengelompokkan ini menggunakan algoritma K-Means sebagai metode yang digunakan. Algoritma K-Means akan melakukan pengclusteran penjualan bahan bangunan sehingga didapatkan pengetahuan yang digunakan untuk pengambilan keputusan dalam penjualan bahan bangunan. Data mining dapat menghasilkan berbagai pengetahuan yang salah satunya untuk menentukan bahan bangunan yang paling banyak terjadi proses transaksi penjualan. Sehingga bahan bangunan yang paling banyak terjadi proses transaksi penjualan dapat dilakukan analisa dalam pengadaan stock bahan bangunan.
\end{abstract}

Keywords: Algoritma K-Means, Cluster, Bahan Bangunan

\section{PENDAHULUAN}

Pada saat sekarang ini proses penjualan mengalami perkembangan yang sangat pesat seiring perkembangan teknologi. Berbagai cara dan metode yang dilakukan para pihak enterprenuer untuk meningkatkan penjualan barang termasuk pada penjualan bahan bangunan. Untuk itu diperlukan suatu analisa dalam bisnis penjualan. Analisa yang digunakan menggunakan salah satu metode yang ada pada data mining yaitu clustering.

Nama lain dari data mining yaitu knowledge discovery in database (KDD), yang semua prosesnya adalah kegiatan yang meliputi pengumpulan, pemakaian data historis untuk menemukan keteraturan, pola atau hubungan dengan set data yang berukuran besar. Output dari data mining dapat digunakan untuk memperbaiki pengambilan keputusan di masa depan (Tacbir Hendro Pudjiantoro et al., 2011). Dalam literatur data mining beberapa teknik yang sering disebut yaitu : clustering, classification, association rule mining, neural network, dan genetic algorithm (Lindawati, 2008).

Salah satu teknik data mining yang dikenal yaitu clustering. Menurut keilmuan data mining clustering adalah pengelompokan sejumlah data atau objek ke dalam cluster (group) sehingga setiap dalam cluster tersebut akan berisi data yang semirip mungkin dan 
berbeda dengan objek dalam cluster yang lainnya (Alfina et al., 2012). Metode clustering merupakan salah satu metode pada data mining. Pada clustering yang menggunakan $\mathrm{K}$ Means sering terjadi permasalahan yaitu belum adanya ketentuan jumlah cluster yang tepat dari sejumlah $\mathrm{k}$ yang diujikan pada data (Jollyta et al., 2019). Data Mining merupakan proses yang dapat memperkerjakan satu atau lebih dari teknik pembelajran komputer (machine learnin) yang dapat secara otomatis menganalis dan mengekstraksi suatu pengetahuan (knowledge) (Hadi, 2018). Clustering mempunyai peranan penting dalam aplikasi data mining, misalnya dalam mengeksplorasi data ilmu pengetahuan, pengaksesan informasi dan text mining, aplikasi basis data spasial, dan analisis web (Andayani, 2007).

Salah satu metode clustering adalah algoritma K-Means. Algoritma K-Means merupakan metode non hierarki dimana pada langkah awalnya mengambil sebagian dari banyaknya komponen populasi untuk dijadikan pusat cluster awal. (Metisen \& Sari, 2015). Algoritma K-Means sudah banyak dikenal karena kemudahan dan kemampuan untuk mengklasifikasi data besar dan outlier dengan sangat cepat (Wijaya, 2011).

\section{METODE PENELITIAN}

\subsection{Algoritma K-Means}

Adapun karakteristik dari algoritma KMeans salah satunya adalah sangat sensitif dalam penentuan titik pusat awal klaster karena K-Means membangkitkan titik pusat klaster awal secara random. Pada saat pembangkitan awal titik pusat yang random tersebut mendekati menemukan titik pusat klaster yang tepat. Sebaliknya, jika awal titik pusat tersebut jauh dari solusi akhir pusat klaster, maka besar kemungkinan ini menyebabkan hasil pengklasteran yang tidak tepat. Akibatnya K-Means tidak menjamin hasil pengklasteran yang unik. Inilah yang menyebabkan metode K-Means sulit untuk mencapai optimum global, akan tetapi hanya minimum lokal. Selain itu, algoritma K-Means hanya bisa digunakan untuk data yang atributnya bernilai numeric (Albar, 2010).

Algoritma dasar dalam k-means adalah (Narwati, 2010):

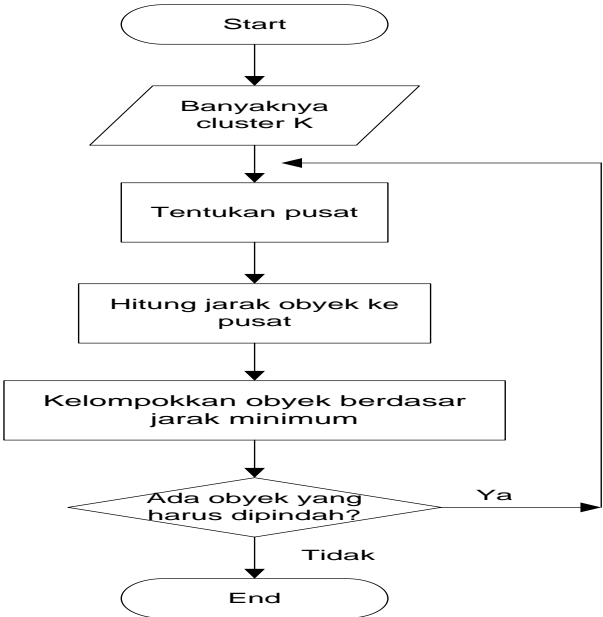

Gambar 1. Algoritma K-Means

1. Tentukan jumlah kluster (k), tetapkan pusat kluster sembarang

2. Hitung jarak setiap data ke pusat kluster menggunakan persamaan

3. Kelompokkan data ke dalam kluster yang dengan jarak yang paling pendek menggunakan persamaan

4. Hitung pusat kluster yang baru menggunakan persamaan

5. Ulangi langkah 2 sampai dengan 4 hingga sudah tidak ada lagi data yang berpindah ke kluster yang lain.

Adapun kerangka kerja pada penelitian ini dapat dilihat pada Gambar 2.

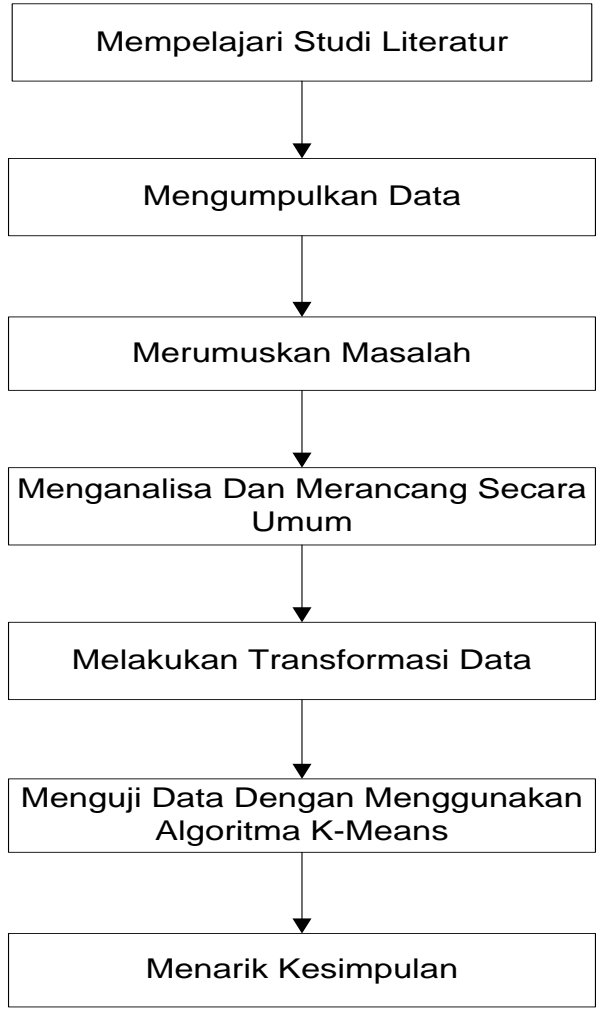

Gambar 2.Kerangka Penelitian 
1. Mempelajari Studi Literatur

Dalam tahap ini, peneliti akan mempelajari literatur yang terkait dengan data mining, clustering, dan algoritma K-Means.

\section{Mengumpulkan Data}

Dalam tahap ini pengumpulan data dilakukan dengan cara langsung observasi pada pada toko bangunan tersebut, data yang dikumpulkan adalah data-data penjualan bahan bangunan dari toko tersebut. Setelah data-data tersebut dikumpulkan dan dipelajari maka langkah selanjutnya yang dilakukan adalah melakukan pengelompokkan data penjualan dan dari hasil pengelompokkan data penjualan tersebut maka dapat memutuskan masalah-masalah yang akan dipecahkan, dan mencari solusinya.

\section{Merumuskan Masalah}

Setelah tahap pengumpulan data dilakukan, maka langkah selanjutnya adalah membuat perumusan masalah yang berkaitan dengan permasalahan yang ada. Bagaimana mengambil keputusan untuk menentukan output apa saja yang akan dihasilkan oleh informasi yang akan dibangun ini dengan menggunakan algoritma K-Means berdasarkan data-data penjualan.

4. Menganalisa dan Merancang Secara Umum Pada tahap ini menjelaskan metode analisa yang dipakai dalam merancang secara umum dalam menentukan bahan bangunan apa yang paling banyak dibeli oleh konsumen.

\section{Mentransformasikan Data}

Pada tahap ini merupakan proses untuk melakukan transformasi data yang didapatkan. Sehinnga data ini dilakukan penginisialisasian agar lebih mudah melakukan pengujian yang merupakan tahap selanjutnya.

6. Menguji Data Dengan Algoritma K-Means Tahap berikutnya setelah melakukan transformasi data. Sehingga data yang sudah melakukan pengtransformasian dilakukan pengujian dengan menggunakan algoritma KMeans. Dari data yang diuji didapatkan hasil yang menjadi pengetahuan agar dapat dibuat kebijakan untuk penjulan bahan bangunan.

\section{Menarik Kesimpulan}

Pada akhir pembahasan dilakukan proses penarikan kesimpulan yang bertujuan untuk membandingkan hasil yang diperoleh dari tahap implementasi sistem yang dibuat secara manual.

\section{HASIL DAN PEMBAHASAN}

Proses awal yang dilakukan adalah mengelompokkan data-data penjualan bahan bangunan, kemudian dilakukan asumsi bahwa jumlah inisialisasi centroid $\mathrm{K}=2$ sesuai dengan penelitian yang dilakukan. Pada tabel di bawah ini merupakan sampel data yang digunakan untuk melakukan percobaan perhitungan manual.

Tabel 1. Sample Data Uji Coba

\begin{tabular}{|c|c|c|c|}
\hline No & Barang & Stock & $\begin{array}{l}\text { Jumlah } \\
\text { Terjual }\end{array}$ \\
\hline 1 & Batu Ultra Tebal & 18 & 6 \\
\hline 2 & Batu Ultra Tipis & 16 & 8 \\
\hline 3 & Besi $10 \mathrm{CK}$ & 120 & 60 \\
\hline 4 & Besi 4 Pas & 100 & 48 \\
\hline 5 & Besi 6 Pas & 80 & 72 \\
\hline 6 & Besi 8 CK & 120 & 54 \\
\hline 7 & Cat Bravo $5 \mathrm{~kg}$ & 48 & 24 \\
\hline 8 & Cat Diton 884 & 60 & 55 \\
\hline 9 & $\begin{array}{l}\text { Cat Dulux } \\
\text { Pentalite }\end{array}$ & 36 & 6 \\
\hline 10 & $\begin{array}{l}\text { Cat Nippon } \\
\text { Spot-Less }\end{array}$ & 48 & 16 \\
\hline 11 & Ensel HPP 4 & 20 & 8 \\
\hline 12 & $\begin{array}{l}\text { Ensel Kupu- } \\
\text { Kupu }\end{array}$ & 24 & 18 \\
\hline 13 & Gembok 25 Risk & 36 & 13 \\
\hline 14 & Gembok 40 Risk & 18 & 12 \\
\hline 15 & GRC & 72 & 54 \\
\hline 16 & Kanal & 48 & 24 \\
\hline 17 & $\begin{array}{l}\text { Kawat Beton } \\
21 \mathrm{~kg}\end{array}$ & 48 & 12 \\
\hline 18 & Kawat Duri & 36 & 30 \\
\hline 19 & $\begin{array}{l}\text { Kawat Patri } 1 / 2 \text { - } \\
3 / 4\end{array}$ & 32 & 15 \\
\hline 20 & Keni 2 & 25 & 10 \\
\hline 21 & Keni 3 inci & 30 & 20 \\
\hline 22 & $\begin{array}{l}\text { Keramik Alberta } \\
\text { Brown 40/40 } \\
\text { Keramik }\end{array}$ & 100 & 88 \\
\hline 23 & $\begin{array}{l}\text { Harmoni 40/40 } \\
\text { Cyprus Green } \\
\text { Keramik Picasso }\end{array}$ & 80 & 55 \\
\hline 24 & $\begin{array}{l}\text { 20/25 Dores } \\
\text { Blue }\end{array}$ & 65 & 30 \\
\hline 25 & Kuas $1 / 2$ & 18 & 4 \\
\hline 26 & Kuas 3 & 20 & 14 \\
\hline 27 & Mika Biru & 24 & 10 \\
\hline 28 & Mika Putih & 18 & 5 \\
\hline 29 & $\begin{array}{l}\text { Paku 2/1 : 3/1 : } \\
4 / 1\end{array}$ & 20 & 6 \\
\hline
\end{tabular}


30 Paku GRC

12

4

\section{Penentuan Pusat Awal Cluster}

Pusat awal cluster atau centroid di dapatkan secara random, untuk penentuan awal cluster diasumsikan:

Pusat cluster 1: $(\mathbf{1 8}, \mathbf{4})$

Pusat cluster 2: $(\mathbf{1 0}, \mathbf{5})$

\section{Perhitungan Jarak Pusat Cluster}

Untuk mengukur jarak antara data dengan pusat cluster digunakan Euclidian Distance, kemudian akan didapatkan matrik jarak sebagai berikut : Rumus Euclidian Distance

$D_{e}=\sqrt{\left(x_{i}-s_{i}\right)^{2}+\left(y_{i}-t_{i}\right)^{2}}$

di mana : De adalah Euclidean Distance $i$ adalah banyaknya objek, $(x, y)$ merupakan koordinat object $(s, t)$.

Dari 30 data yang dijadikan sampel telah dipilih pusat awal cluster yaitu $\mathbf{C 1}=$ $(\mathbf{1 8}, \mathbf{4}), \mathbf{C} 2=(\mathbf{1 0}, \mathbf{5})$. Setelah itu kita hitung jarak dari sisa sampel data dengan pusat cluster.

\section{Hitung Euclidian Distance}

Hitung Euclidian Distance dari semua data ke tiap titik pusat pertama :

Tabel 2. Euclidian Distance 1 (D1) iterasi pertama

\begin{tabular}{l}
\hline D1 \\
\hline D11 $=\sqrt{(18-18)^{2}+(6-4)^{2}}=2,0000$ \\
D12 $=\sqrt{(16-18)^{2}+(8-4)^{2}}=4,4721$ \\
D13 $=\sqrt{(120-18)^{2}+(60-4)^{2}}=116,3615$ \\
D14 $=\sqrt{(100-18)^{2}+(48-4)^{2}}=93,0591$ \\
D15 $=\sqrt{(80-18)^{2}+(72-4)^{2}}=92,0217$ \\
D16 $=\sqrt{(120-18)^{2}+(54-4)^{2}}=113,5958$ \\
D17 $=\sqrt{(48-18)^{2}+(24-4)^{2}}=36,0555$ \\
D18 $=\sqrt{(60-18)^{2}+(55-4)^{2}}=66,0681$ \\
D19 $=\sqrt{(36-18)^{2}+(6-4)^{2}}=18,1108$ \\
D110 $=\sqrt{(48-18)^{2}+(16-4)^{2}}=32,3110$ \\
D111 $=\sqrt{(20-18)^{2}+(8-4)^{2}}=4,4721$ \\
D112 $=\sqrt{(24-18)^{2}+(18-4)^{2}}=15,2315$ \\
D113 $=\sqrt{(36-18)^{2}+(13-4)^{2}}=20,1246$ \\
D114 $=\sqrt{(18-18)^{2}+(12-4)^{2}}=8,0000$ \\
D115 $=\sqrt{(72-18)^{2}+(54-4)^{2}}=73,5935$ \\
D116 $=\sqrt{(48-18)^{2}+(24-4)^{2}}=36,0555$ \\
D117 $=\sqrt{(48-18)^{2}+(12-4)^{2}}=31,0483$ \\
D118 $=\sqrt{(36-18)^{2}+(30-4)^{2}}=31,6228$ \\
D119 $=\sqrt{(32-18)^{2}+(24-4)^{2}}=17,8045$ \\
D120 $=\sqrt{(25-18)^{2}+(10-4)^{2}}=9,2195$ \\
D121 $=\sqrt{(30-18)^{2}+(20-4)^{2}}=20,0000$ \\
D122 $=\sqrt{(100-18)^{2}+(88-4)^{2}}=117,3882$
\end{tabular}

$$
\begin{aligned}
& \text { D123 }=\sqrt{(80-18)^{2}+(55-4)^{2}}=80,2808 \\
& \text { D124 }=\sqrt{(65-18)^{2}+(30-4)^{2}}=53,7122 \\
& \text { D125 }=\sqrt{(18-18)^{2}+(4-4)^{2}}=0,0000 \\
& \text { D126 }=\sqrt{(20-18)^{2}+(14-4)^{2}}=10,1980 \\
& \text { D127 }=\sqrt{(24-18)^{2}+(10-4)^{2}}=8,4853 \\
& \text { D128 }=\sqrt{(18-18)^{2}+(5-4)^{2}}=1,0000 \\
& \text { D129 }=\sqrt{(20-18)^{2}+(6-4)^{2}}=2,8284 \\
& \text { D130 }=\sqrt{(12-18)^{2}+(4-4)^{2}}=6,0000
\end{aligned}
$$

Dengan cara yang sama hitung jarak tiap titik ke titik pusat ke-2 dan kita akan mendapatkan :

Tabel 3. Euclidian Distance 2 (D2) iterasi pertama

\begin{tabular}{l} 
D2 \\
\hline D21 $=\sqrt{(18-10)^{2}+(6-5)^{2}}=8,0622$ \\
D22 $=\sqrt{(16-10)^{2}+(8-5)^{2}}=6,7082$ \\
D23 $=\sqrt{(120-10)^{2}+(60-5)^{2}}=122,9837$ \\
D24 $=\sqrt{(100-10)^{2}+(48-5)^{2}}=99,7446$ \\
D25 $=\sqrt{(80-10)^{2}+(72-5)^{2}}=96,8968$ \\
D26 $=\sqrt{(120-10)^{2}+(54-5)^{2}}=120,4201$ \\
D27 $=\sqrt{(48-10)^{2}+(24-5)^{2}}=42,4852$ \\
D28 $=\sqrt{(60-10)^{2}+(55-5)^{2}}=70,7106$ \\
D29 $=\sqrt{(36-10)^{2}+(6-5)^{2}}=26,0192$ \\
D210 $=\sqrt{(48-10)^{2}+(16-5)^{2}}=39,5601$ \\
D211 $=\sqrt{(20-10)^{2}+(8-5)^{2}}=10,4403$ \\
D212 $=\sqrt{(24-10)^{2}+(18-5)^{2}}=19,1049$ \\
D213 $=\sqrt{(36-10)^{2}+(13-5)^{2}}=27,2029$ \\
D214 $=\sqrt{(18-10)^{2}+(12-5)^{2}}=10,6301$ \\
D215 $=\sqrt{(72-10)^{2}+(54-5)^{2}}=79,0253$ \\
D216 $=\sqrt{(48-10)^{2}+(24-5)^{2}}=42,4852$ \\
D217 $=\sqrt{(48-10)^{2}+(12-5)^{2}}=38,6393$ \\
D218 $=\sqrt{(36-10)^{2}+(30-5)^{2}}=36,0693$ \\
D219 $=\sqrt{(32-10)^{2}+(15-5)^{2}}=24,1660$ \\
D220 $=\sqrt{(25-10)^{2}+(10-5)^{2}}=15,8113$ \\
D221 $=\sqrt{(30-10)^{2}+(20-5)^{2}}=25$ \\
D222 $=\sqrt{(100-10)^{2}+(88-5)^{2}}=122,4295$ \\
D223 $=\sqrt{(80-10)^{2}+(55-5)^{2}}=86,0232$ \\
D224 $=\sqrt{(65-10)^{2}+(30-5)^{2}}=60,4152$ \\
D225 $=\sqrt{(18-10)^{2}+(4-5)^{2}}=8,0622$ \\
D226 $=\sqrt{(20-10)^{2}+(14-5)^{2}}=13,4536$ \\
D227 $=\sqrt{(24-10)^{2}+(10-5)^{2}}=14,8660$ \\
D228 $=\sqrt{(18-10)^{2}+(5-5)^{2}}=8$ \\
D229 $=\sqrt{(20-10)^{2}+(6-5)^{2}}=10,0498$ \\
D230 $=\sqrt{(12-10)^{2}+(4-5)^{2}}=2,2360$ \\
\hline
\end{tabular}

Dari hasil perhitungan Euclidian Distance maka didapatkan hasil iterasi seperti yang ada pada tabel di bawah ini : 
Tabel 4. Hasil Iterasi 1

\begin{tabular}{|c|c|c|c|c|c|c|}
\hline \multirow{2}{*}{$\mathbf{M}$} & \multicolumn{2}{|c|}{ CENTROID 1} & \multicolumn{2}{|c|}{ CENTROID 2} & \multirow[t]{2}{*}{$\mathrm{C1}$} & \multirow[t]{2}{*}{$\mathrm{C2}$} \\
\hline & 18 & 4 & 10 & 5 & & \\
\hline M1 & 2,0000 & & 8,06225 & & OK & \\
\hline M2 & 4,4721 & & 6,70820 & & $\mathrm{OK}$ & \\
\hline M3 & 116,3615 & & 122,983 & & OK & \\
\hline M4 & 93,0591 & & 99,7446 & & OK & \\
\hline M5 & 92,0217 & & 96,8968 & & OK & \\
\hline M6 & 113,5958 & & 120,420 & & OK & \\
\hline M7 & 36,0555 & & 42,4852 & & OK & \\
\hline M8 & 66,0681 & & 70,7106 & & OK & \\
\hline M9 & 18,1108 & & 26,0192 & & OK & \\
\hline M10 & 32,3110 & & 39,5600 & & $\mathrm{OK}$ & \\
\hline M11 & 4,4721 & & 10,4403 & & OK & \\
\hline M12 & 15,2315 & & 19,1049 & & OK & \\
\hline M13 & 20,1246 & & 27,2029 & & OK & \\
\hline M14 & 8,0000 & & 10,6301 & & OK & \\
\hline M15 & 73,5935 & & 79,0253 & & OK & \\
\hline M16 & 36,0555 & & 42,4852 & & OK & \\
\hline M17 & 31,0483 & & 38,6393 & & OK & \\
\hline M18 & 31,6228 & & 36,0693 & & $\mathrm{OK}$ & \\
\hline M19 & 17,8045 & & 24,1660 & & OK & \\
\hline M20 & 9,2195 & & 15,8113 & & OK & \\
\hline M21 & 20,0000 & & 25 & & OK & \\
\hline M22 & 117,3882 & & 122,4295 & & OK & \\
\hline M23 & 80,2808 & & 86,02325 & & OK & \\
\hline M24 & 53,7122 & & 60,41522 & & OK & \\
\hline M25 & 0,0000 & & 8,062257 & & OK & \\
\hline M26 & 10,1980 & & 13,45362 & & OK & \\
\hline M27 & 8,4853 & & 14,86606 & & OK & \\
\hline M28 & 1,0000 & & 8 & & $\mathrm{OK}$ & \\
\hline M29 & 2,8284 & & 10,04987 & & $\mathrm{OK}$ & \\
\hline M30 & 6,0000 & & 2,236067 & & & OK \\
\hline
\end{tabular}

Dari hasil diperoleh hasil bahwa untuk anggota $\mathrm{C} 1$ adalah $\mathrm{m} 1, \mathrm{~m} 2, \mathrm{~m} 3, \mathrm{~m} 4, \mathrm{~m} 5, \mathrm{~m} 6$, $\mathrm{m} 7, \mathrm{~m} 8, \mathrm{~m} 9, \mathrm{~m} 10, \mathrm{~m} 11, \mathrm{~m} 12, \mathrm{~m} 13, \mathrm{~m} 14, \mathrm{~m} 15$, $\mathrm{m} 16, \mathrm{~m} 17, \mathrm{~m} 18, \mathrm{~m} 19, \mathrm{~m} 20, \mathrm{~m} 21, \mathrm{~m} 22, \mathrm{~m} 23$, $\mathrm{m} 24, \mathrm{~m} 25, \mathrm{~m} 26, \mathrm{~m} 27, \mathrm{~m} 28, \mathrm{~m} 29$. Sedangkann untuk anggota $\mathrm{C} 2$ adalah $\mathrm{m} 30$.

\section{Penentuan Pusat Cluster Baru}

Tentukan posisi centroid baru $(\mathrm{Ck})$ dengan cara menghitung nilai rata-rata dari data data yang ada pada centroid yang sama.

$$
C k=\left(\frac{1}{n k}\right) \sum d i
$$

Dimana $n k$ adalah jumlah dokumen dalam cluster $k$ dan $d i$ adalah dokumen dalam cluster $k$. Sehingga didapat centroid baru yaitu: C1 $(43,3047, \quad 49,3081)$ dan C2(7,0911, 1,9472).

\section{Ulangi Langkah 2 Hingga Posisi Data Tidak Berubah}

Berikut hasil-hasil iterasi yang dilakukan setelah melakukan perhitungan Euclian Distance.

Tabel 5. Hasil Iterasi 2

\begin{tabular}{c|c|c|c|c|c|c}
\hline \multirow{2}{*}{ M } & \multicolumn{2}{|c|}{ CENTROID 1 } & \multicolumn{2}{c|}{ CENTROID 2 } & \multirow{2}{*}{ C1 } & C2 \\
\cline { 2 - 4 } & $\mathbf{4 3 , 3 0 4 7}$ & $\mathbf{4 9 , 3 0 8 1}$ & $\mathbf{7 , 0 9 1 1}$ & $\mathbf{1 , 9 4 7 2}$ & & \\
\hline M1 & 25,7400 & \multicolumn{3}{|c|}{11,6373} & & OK
\end{tabular}

\begin{tabular}{lllll} 
M2 & 37,6025 & 10,7705 & & OK \\
M3 & 20,6438 & 126,958 & OK & \\
M4 & 36,1227 & 103,696 & OK & \\
M5 & 43,3612 & 101,109 & OK & \\
M6 & 32,1867 & 124,329 & OK & \\
M7 & 68,6397 & 46,4743 & OK & \\
M8 & 37,1341 & 74,9262 & OK & \\
M9 & 29,0429 & 29,1915 & & OK \\
M10 & 51,8957 & 43,2552 & OK & \\
M11 & 42,3058 & 14,2574 & & OK \\
M12 & 43,7928 & 23,3152 & & OK \\
M13 & 51,0250 & 30,9497 & & OK \\
M14 & 49,1804 & 14,8344 & & OK \\
M15 & 55,0710 & 83,2025 & OK & \\
M16 & 25,7400 & 46,4743 & OK & \\
M17 & 37,6025 & 42,1259 & OK & \\
M18 & 20,6438 & 40,2825 & OK & \\
M19 & 36,1227 & 28,1216 & & OK \\
M20 & 43,3612 & 19,6360 & & OK \\
M21 & 32,1867 & 29,1671 & & OK \\
M22 & 68,6397 & 126,637 & OK & \\
M23 & 37,1341 & 90,1681 & OK & \\
M24 & 29,0429 & 64,3459 & OK & \\
M25 & 51,8957 & 11,1003 & & OK \\
M26 & 42,3058 & 17,6609 & & OK \\
M27 & 43,7928 & 18,7285 & & OK \\
M28 & 51,0250 & 11,3279 & & OK \\
M29 & 49,1804 & 13,5301 & & OK \\
M30 & 55,0710 & 5,32081 & & OK \\
\hline & & & &
\end{tabular}

Tabel 6. Hasil Iterasi 3

\begin{tabular}{|c|c|c|c|c|c|c|}
\hline \multirow{2}{*}{$\mathbf{M}$} & \multicolumn{2}{|c|}{ CENTROID 1} & \multicolumn{2}{|c|}{ CENTROID 2} & \multirow[t]{2}{*}{ C1 } & \multirow[t]{2}{*}{$\mathrm{C2}$} \\
\hline & 37,0696 & 78,9186 & 44,1996 & 19,4467 & & \\
\hline M1 & 75,3709 & & 85,9666 & & & OK \\
\hline M2 & 73,9822 & & 62,6815 & & & OK \\
\hline M3 & 85,0609 & & 63,5886 & & OK & \\
\hline M4 & 70,1155 & & 83,3044 & & & OK \\
\hline M5 & 43,4843 & & 5,93085 & & $\mathrm{OK}$ & \\
\hline M6 & 86,5932 & & 38,9061 & & & OK \\
\hline M7 & 55,9958 & & 15,7495 & & & OK \\
\hline M8 & 33,1346 & & 5,13059 & & $\mathrm{OK}$ & \\
\hline M9 & 72,9264 & & 26,7703 & & & OK \\
\hline M10 & 63,8610 & & 20,2513 & & & $\mathrm{OK}$ \\
\hline M11 & 72,9439 & & 10,4304 & & & $\mathrm{OK}$ \\
\hline M12 & 62,3048 & & 27,2373 & & & $\mathrm{OK}$ \\
\hline M13 & 65,9273 & & 44,3484 & & & OK \\
\hline M14 & 69,5827 & & 5,93085 & & & OK \\
\hline M15 & 42,9076 & & 8,36044 & & OK & \\
\hline M16 & 55,9958 & & 13,3643 & & & OK \\
\hline M17 & 67,8054 & & 12,9847 & & & OK \\
\hline M18 & 48,9303 & & 21,3978 & & & OK \\
\hline M19 & 64,1193 & & 14,2103 & & & OK \\
\hline M20 & 69,9675 & & 88,3924 & & & $\mathrm{OK}$ \\
\hline M21 & 59,3412 & & 50,4549 & & & OK \\
\hline M22 & 63,5822 & & 23,3243 & & $\mathrm{OK}$ & \\
\hline M23 & 49,1438 & & 30,4141 & & $\mathrm{OK}$ & \\
\hline M24 & 56,3306 & & 24,8050 & & & OK \\
\hline M25 & 77,3075 & & 22,2994 & & & OK \\
\hline M26 & 67,1252 & & 29,9186 & & & OK \\
\hline M27 & 70,1469 & & 27,6845 & & & OK \\
\hline M28 & 76,3388 & & 35,7129 & & & OK \\
\hline M29 & 74,8899 & & 85,9666 & & & OK \\
\hline M30 & 79,0018 & & 62,6815 & & & OK \\
\hline
\end{tabular}


Tabel 7. Hasil Iterasi 4

\begin{tabular}{|c|c|c|c|c|c|c|}
\hline \multirow{2}{*}{$\mathbf{M}$} & \multicolumn{2}{|c|}{ CENTROID 1} & \multicolumn{2}{|c|}{ CENTROID 2} & \multirow[t]{2}{*}{$\mathbf{C 1}$} & \multirow[t]{2}{*}{$\overline{\mathrm{C} 2}$} \\
\hline & 54,9162 & 54,9162 & 64,1103 & 25,4199 & & \\
\hline M1 & 61,2831 & & 50,0330 & & & OK \\
\hline M2 & 60,9559 & & 51,1670 & & & OK \\
\hline M3 & 65,2819 & & 65,7224 & & OK & \\
\hline M4 & 45,6111 & & 42,4019 & & & OK \\
\hline M5 & 30,3487 & & 49,2157 & & OK & \\
\hline M6 & 65,0902 & & 62,7731 & & & OK \\
\hline M7 & 31,6805 & & 16,1729 & & & OK \\
\hline M8 & 5,0844 & & 29,8643 & & OK & \\
\hline M9 & 52,4464 & & 34,1662 & & & $\mathrm{OK}$ \\
\hline M10 & 39,5261 & & 18,6623 & & & $\mathrm{OK}$ \\
\hline M11 & 58,4832 & & 47,4255 & & & OK \\
\hline M12 & 48,1522 & & 40,7909 & & & OK \\
\hline M13 & 45,9870 & & 30,7319 & & & OK \\
\hline M14 & 56,6094 & & 48,0236 & & & $\mathrm{OK}$ \\
\hline M15 & 17,1083 & & 29,6490 & & OK & \\
\hline M16 & 31,6805 & & 16,1729 & & & OK \\
\hline M17 & 43,4700 & & 20,9676 & & & OK \\
\hline M18 & 31,2833 & & 28,4811 & & & $\mathrm{OK}$ \\
\hline M19 & 46,0268 & & 33,7587 & & & $\mathrm{OK}$ \\
\hline M20 & 53,9672 & & 42,0404 & & & $\mathrm{OK}$ \\
\hline M21 & 42,8949 & & 34,5383 & & & $\mathrm{OK}$ \\
\hline M22 & 55,9202 & & 72,1410 & & OK & \\
\hline M23 & 25,0838 & & 33,5777 & & $\mathrm{OK}$ & \\
\hline M24 & 26,8794 & & 4,6656 & & & OK \\
\hline M25 & 62,8910 & & 50,8427 & & & OK \\
\hline M26 & 53,7893 & & 45,5647 & & & $\mathrm{OK}$ \\
\hline M27 & 54,5279 & & 42,9723 & & & OK \\
\hline M28 & 62,0842 & & 50,4296 & & & $\mathrm{OK}$ \\
\hline M29 & 60,0995 & & 48,1961 & & & $\mathrm{OK}$ \\
\hline M30 & 66,5904 & & 56,3410 & & & OK \\
\hline
\end{tabular}

Pada iterasi yang dilakukan mulai iterasi 1 sampai iterasi 5 didapatkan bahwa pada iterasi 1 mempunyai pola cluster centroid yang berbeda dengan pola cluster iterasi 2 . Sedangkan pada iterasi selanjutnya seperti iterasi 3 juga mempunyai pola cluster centroid yang berbeda dengan iterasi 1 dan 2. Makanya dilanjutkan iterasi 4 untuk mencari pola cluster centroid yang sama dengan iterasi 1, 2, 3 . Tetapi semuanya mempunyai pola yang berbeda dan dilanjutkan iterasi 5. Pada iterasi 5 mempunyai pola cluster centroid yang sama dengan pola cluster centroid iterasi 4 yaitu mempunyai anggota dari :

$\mathrm{C} 1: \mathrm{m} 3, \mathrm{~m} 5, \mathrm{~m} 8, \mathrm{~m} 15, \mathrm{~m} 22$ dan $\mathrm{m} 23$

$\mathrm{C} 2: \mathrm{m} 1, \mathrm{~m} 2, \mathrm{~m} 4, \mathrm{~m} 6, \mathrm{~m} 7, \mathrm{~m} 9, \mathrm{~m} 10, \mathrm{~m} 11, \mathrm{~m} 12$, $\mathrm{m} 13,14, \mathrm{~m} 16, \mathrm{~m} 17, \mathrm{~m} 18, \mathrm{~m} 19, \mathrm{~m} 20, \mathrm{~m} 21$, m24,m25,m26,m27,m28,m29 dan m30.

Karena hasil iterasi sudah ada yang sama iterasi dihentikan

\section{SIMPULAN}

Hasil dari penelitian ini adalah Dengan menggunakan algoritma K-Means yang mempunyai data training sebanyak 30 data. Iterasi yang digunakan dalam pengolahan pada algoritma K-Means sebanyak 5 iterasi. Pada iterasi 4 dan 5 mempunyai pola cluster centroid yang sama.Clustering yang dihasilkan digunakan untuk menarik kesimpulan dalam data penjualan bahan bangunan dengan menggunakan algoritma K-Means untuk menentukan penjualan bahan bangunan yang paling banyak dibeli oleh konsumen Pemilihan variabel dan atribut yang akan digunakan sangat mempengaruhi knowledge yang digunakan. Dari hasil yang didapatkan diperoleh bahan bangunan yang laris dibeli konsumen yaitu : Batu Ultra Tipis,Besi 4 Pas, Cat Bravo 5kg, Gembok 40 Risk, Keni 3 inci,Keramik Alberta Brown 40/40.

\section{UCAPAN TERIMAKASIH}

Ucapan terima kasih kepada pihak-pihak yang telah memberikan dukungan terhadap penelitian.

\section{DAFTAR PUSTAKA}

Albar, I. \& F. (2010). Identifikasi Dengan Menggunakan Algoritma K Means Pada Plat Kendaraan Identification with $K$ Means Algorithm on Plate Number of Vehicle. 6, 1-8.

Alfina, T., Santosa, B., \& Barakbah, A. R. (2012). Analisa perbandingan metode hierarchical clustering, k-means dan gabungan keduanya dalam cluster data (studi kasus: Problem kerja praktek teknik industri its). Jurnal Teknik Its, 1(1), A521--A525.

Andayani, S. (2007). Pembentukan Cluster dalam Knowledge Discovery in database dengan Algoritma K-Means. SEMNAS Matematika Dan Pendidikan Matematika Dengan Tema"Trend Penelitian Matematika Dan Pendidikan Matematika Di Era Global.

Hadi, F. (2018). Penerapan Metode Algoritma C4. 5 dalam Menganalisa Pegajuan Kredit pada Koperasi Jasa Keuangan Syariah Kelurahan Limau Manis Selatan. Indonesian Journal of Computer Science, 7(1), 28-42.

Jollyta, D., Efendi, S., Zarlis, M., \& Mawengkang, H. (2019). Optimasi Cluster Pada Data Stunting: Teknik Evaluasi Cluster Sum of Square Error dan Davies Bouldin Index. Prosiding Seminar Nasional Riset Information 
Science (SENARIS), 1(September), 918. https://doi.org/10.30645/senaris.v1i0.10 0

Lindawati. (2008). Data Mining Dengan Teknik Clustering Dalam Pengklasifikasian Data Mahasiswa Studi Kasus Prediksi Lama Studi Mahasiswa Universitas Bina Nusantara. Universitas Stuttgart, 2008(semnasIF), 174-180.

Metisen, B. M., \& Sari, H. L. (2015). Analisis Clustering Menggunakan Metode KMeans Dalam Pengelompokkan Penjualan Produk Pada Swalayan Fadhila. Media Infotama, 11(2), 110 118.

Narwati, N. (2010). Pengelompokan Mahasiswa Menggunakan Algoritma KMeans. Jurnal Dinamika Informatika, 2(2).

Tacbir Hendro Pudjiantoro, Renaldi, F., \& Teogunadi, A. (2011). Penerapan Data Mining untuk Menganalisa Kemungkinan Pengunduran Diri Calon Mahasiswa Baru. Konferensi Nasional Sistem Informatika.

Wijaya, A. (2011). Analisi algortima k-means untuk sistem pendukung keputusan penjurusan siswa di man binong subang. Universitas Komputer Indonesia, 112. 